West Ukrainian National University, 11, Lvivska Str., Ternopil, Ukraine

\title{
STUDENTS' MOTIVATION IN DEVELOPING TRANSLATION COMPETENCE
}

Students' language learning motivation is an important factor to ensure the quality of higher education in Ukraine in the context of its integration into the European Higher Education Area. The present study reveals the findings that showcase both pedagogical and psychological factors influencing students' foreign language learning motivation in translation competence. The authors used a set of basic theoretical research methods to analyze, synthetize and classify scientific and methodological sources on the research problem; empirical methods of questionnaire surveys with direct and indirect questioning to represent learning motivational characteristics, statistical analysis to summarize the research results. Both psychological and pedagogical diagnostics of the socially heterogeneous respondents' motivation made it possible to determine the external socio-cultural and internal self-concept motives in their self-improvement and selfregulated learning. It is established that the respondents' external motives have arisen due to such stimulating factors as "competitive advantage in the labor market" and "career growth potential". Internal motives are mainly related to the satisfaction of a student's personal needs in the foreign language learning (interest, awareness of the insufficient level of communicative competence, internal belief in the need for self-improvement of foreign language translation skills, etc.). Analysis of the diagnostics results provided an opportunity to distinguish the obstacles to the self-development of respondents in translation education. Experimental testing of the learning motivation within the internal and external mediation allowed to reveal the dominance of internal motives over external ones in all categories of respondents. Insufficient or low level of independent self-regulated learning has been identified as the main obstacle to self-improvement of foreign language translation competence. The paper contributes to the current understanding of translation education, especially in the context of Ukraine, by investigating factors influencing students' learning motives and their pedagogical and theoretical implications.

Keywords: external and internal motives, self-improvement, foreign language translation competence, social characteristics of respondents.

Подано до редакичї 25.06.2021

УДК: 378. 147

DOI: https://doi.org/10.24195/2414-4665-2021-3-7

\author{
Viktoriya Bilytska, \\ Doctor of Philosophy, Senior Lecturer, \\ Department of Theory, Practice, and Translation of German, \\ National Technical University of Ukraine \\ "Igor Sikorsky Kyiv Polytechnic Institute”, \\ 37, Peremohy Avenue, Kyiv, Ukraine
}

\section{CULTURAL COMPETENCE AS ONE OF THE KEY COMPETENCIES IN THE RENEWAL UKRAINIAN EDUCATION SYSTEM}

The aim of the article is to specify the content of cultural competence and the expected results of its development in the context of basic secondary education. Cultural competence as the educational term was first defined in the Law "On Education" in Ukraine (2017) and in the State Standard of the Basic Secondary Education (2020) for the 5th - 12th classes $^{l}$. The article specifies the process of cultural competence attainment and the expected learning outcomes. The results of the study are formulated based on a logical-semantic analysis and structural-functional clarification of the cultural competence essence, separation of its structural components, and interpretation of the provisions of adopted Regulation documents, Standards, and Recommendations on Education Policy, as well as a reflective analysis of research results on the concept of cultural competence in national and international researches. The cultural

1 The reform of Ukrainian education has started and came into force in 2017 for first-grade students of the same year. The students of all the rest grades continued their studies according to the previous Law on Education (1991).

Therefore, it is expected that secondary education students would be taught cultural competence in 2022 according to the new Law "On Education" (2017) and the new Standard of the Basic Secondary Education (2020). 
competence of a person is manifested in the form of a core competence that allows him or her to independently understand and freely use at his or her discretion the whole range of acquired competencies and expertise in socio-cultural and general, institutional and conventional norms and regulators of behavior in mobile social communication, including in different languages. Scientific discussion of the competence concept is an up-to-date issue due to the reformation of the Ukrainian educational system, according to the world model.

Keywords: cultural competence, key competence, development of cultural competence, basic secondary education, Ukrainian educational system, Law On Education of Ukraine, the State Standard of the Basic Secondary Education of Ukraine.

\section{Introduction and the current state of the research problem}

The Ukrainian educational system, while under reform to meet the world standards, in the course of its modernization via integration of technologies into the educational process, while making progress and undergoing changes under the influence of external circumstances, is modeling itself on leading countries in terms of quality of education. Shaping up of the new pedagogical paradigm as a result of a radical change in the approaches within the education system as well as the rethinking of socio-cultural policy principles is focused on humanistic values, providing a background for harmonious personality development, transferring the basics of social, national and world culture to a new generation, formation of a system of values on the basis of universal human and cultural values.

\section{Aim and tasks}

The aim of the present article is to specify the content of cultural competence as defined in the State Standard of Basic Secondary Education, as well as the expected outcomes of its formation in the context of lifelong learning.

In accordance with the aim of the conceptual framework of the study the following tasks were defined:

- to investigate the essence and structure of cultural competence as the basis for educational policy in the State Standard of basic secondary education of Ukraine;

- to identify the organizational and pedagogical conditions for the development of cultural competence in the basic secondary education of Ukraine;

- to summarise the findings in the context of national and international reform trends.

\section{Research methods}

To achieve the research objective at its different stages, the complex of interconnected research methods was used. Analysis and synthesis were used to determine the final points of the thesis (object, subject, aim, tasks). Summarizing and systematizing were aimed to clarify the state of the problem in sociological and pedagogical research. The critical analysis helped to identify possible approaches to the problem and ensure the logic of the study, structural-functional method - to clarify the essence and the structural components of the phenomenon of cultural competence. Method of logical-semantic analysis was used to understand the concept "cultural competence", synthesis, abstraction - to consider theoretical approaches to cultural competence of pupils. The Law of Ukraine "On Education" (2017), the National Doctrine for Education Development (2002), as well as the State Standard of Basic Secondary Education (2020) were studied with the method of document analysis. Using the monograph method succeeded in showing the achieved results in a logical order.
The reform of the national system of education in Ukraine is carried out owing to consistent work of the United National within the framework of the UNDP Project "Education, Innovation and Renewal for Improved Well-Being and Poverty Reduction" in the course of which a strategy for the development of education over the next quarter of a century, the National Doctrine for the Development of Education, has been formed. Based on the National Doctrine (2011), the Law of Ukraine "On Education" (2017) was developed and launched for implementation. The State Standard of Basic Secondary Education provides the background for the continuation of the reform in Grades 5-9 and its implementation from 2022. The document determines the structure and content of basic secondary education and provides for the implementation of a number of innovative approaches, notably in the course of evaluation of outcomes and organization of the educational process.

\section{Research results}

The State Standard of Basic Secondary Education is closely linked to the State Standard of Primary Education (2019), as it continues the idea of a competency approach and other reformation principles. The content of education areas in the document is presented through the "core of content", which outlines the range of concepts for mandatory learning, and will be expanded at the level of model training programs.

The Standard describes cross-cutting skills and mandatory learning outcomes through their specific results and benchmarks for assessment in respect of each of the competencies that students must master at the end of each of the two cycles - adaptation (Grades 5-6) and basic subject learning (Grades 7-9). The concept of the State Standard of Basic Secondary Education defines the content framework of the educational process in the form of values, key competencies, and common skills (soft skills). The key competencies include fluency in the national language, ability to communicate in mother tongue (if different from the national language) and foreign languages, mathematical competence, competencies in natural sciences, technologies, innovative thinking, environmental competence, information and communication competence, lifelong learning, civic and social competencies, entrepreneurship and financial awareness. There is no division into subjects in the document; it includes education areas instead which means that the authors of educational and training programs will be able to both implement a particular educational area through a single subject and to combine them for integration purposes.

The cross-cutting skills in all key competencies include the following: 
1. reading with understanding, which involves an ability to perceive, understand information recorded (transmitted) in different ways or reproduced using technical devices. This includes the ability to identify assumptions and information presented implicitly in the text, to prove the reliability of arguments, support one's own conclusions with facts from the text and implicit evidence, to express ideas pertaining to a new understanding of the text upon its analysis and selection of counterarguments;

2 . expressing one's own opinion orally and in writing, which involves an ability to verbally convey one's own thoughts, feelings, beliefs, taking into account communication purpose and participants and choosing the appropriate speech strategies;

3. critical and systematic thinking which is manifested in identifying the characteristics of phenomena, events, ideas, the ability to analyze and evaluate the probability and weight of arguments in judgments, take into account opposing views and counter-arguments, distinguishing facts and their interpretations, recognizing attempts to manipulate with data using various resources and ways to assess the reliability of quantitative and qualitative evidence and the reliability of information sources;

4. creativity, which involves creative thinking, producing new ideas, using other persons' ideas and their refinement, using the knowledge from various subjects and areas to create new objects, ideas, ability to test new ideas with due regard for the reasonable risk posed when expressing and implementing new ideas;

5. the initiative, which involves actively searching for and proposing solutions for the development and testing of ideas and solving problems (creating values);

6. logical reasoning of one's position, which involves the ability to express consistent, unambiguous, well-grounded reasoning in the form of conclusions/judgments as a manifestation of one's own attitude to events, phenomena, and processes;

7. modulating emotions in a constructive manner, which involves the ability to recognize one's own emotions and other persons' emotional state, understand how emotions can help and interfere with activities, and take measures relevant to the emotional state, being aware that a person can control his/her emotions, knows the ways of setting one's mind on productive activity;

8. risk assessment, which involves the ability to distinguish between acceptable and unacceptable risks, taking into account a large number of factors;

9. decision-making, which involves the ability to assess ways to solve problems, taking into account their ethical, legal, environmental, and social consequences;

10. problem-solving, which involves the ability to formulate problems and present them in different ways, select and obtain data to solve problems from reliable sources, using various problem-solving techniques and strategies;

11. cooperation with others, which involves the ability to justify the benefits of interaction during collaborative activities, plan one's own and group's work, support group members, help and encourage others to achieve a common goal.
Cultural Competence in education Areas of the State Standard

Cultural competence as a level of determining the horizons of perception of objective reality allows a person to independently understand and freely use at his/her discretion the full range of acquired competencies and competencies relating to socio-cultural and social, institutional, and conventional norms and behavior regulators in the course of responsive social communication, as well as in different languages.

In the State Standard, cultural competence is defined as a sustainable interest in mastering Ukraine's and the world's cultural and artistic achievements, respect for the cultural traditions of Ukrainians, indigenous peoples and national minorities of Ukraine, other countries and nations, and as an ability to understand and respect creative ways of expressing and conveying ideas and meanings in different cultures through different arts and other cultural forms; the desire to develop and express one's own ideas and feelings through culture and art.

For each education area, the goal and groups of general outcomes are described in the State Standard, which is defined more precisely through the mandatory outcomes for each cycle. That is why each education area has a potential for the development of each competence. Let us have a broader look at cultural competence within each of the 9 education areas:

1. Education area "Languages and Literature" aims to develop competent speakers and readers who speak Ukrainian are able to communicate in the languages of relevant indigenous peoples and national minorities, as well as in foreign languages, for spiritual, cultural, and national self-expression and intercultural dialogue. Within this area, cultural competence covers the following skills and attitudes:

Skills:

- to use language for spiritual, cultural, and national self-expression;

- to read works of literature, use the experience of interaction with works of art in life situations;

- to create texts, expressing one's own ideas, experience, and feelings, selecting appropriate artistic means;

- to select literature to read in order to derive satisfaction and benefit from reading.

Attitudes:

- the need to read works of literature for pleasure and reflection on what is read;

- openness to intercultural communication; interest in world cultural achievements.

Section "knowledge" of this education area, in its part "communications", also assumes the acquisition of knowledge on communication interaction, implicit content of the message, typical strategies of talk exchange, principles of communication ethics, socio-cultural norms, the socio-cultural context of communication, online interaction. The part "text/media text" covers knowledge of the cultural and historical context, moral and ethical values, literary genres, styles and trends, reading experience, and aesthetic value of the text. 
Cultural competence in a multilingual and multicultural world is becoming more important in learning a foreign language. It is covered in the foreign languages section and is represented by a separate area of knowledge called "socio-cultural knowledge (society and culture of the country of the studied language"). Cultural competence includes awareness of the everyday life of the country whose language is being studied, living conditions, interpersonal relationships, values, beliefs, attitudes towards national identity, history, traditions, art, etc.; social habits/conventions (punctuality, clothing, food, behavior, customs, celebrations, etc.).

Mandatory learning outcomes in the Languages and Literatures education area assume the acquisition of cultural competence through verbal interaction with others, perception, and use of information to achieve life goals in various communicative situations as well as the perception of verbal information and written texts in a foreign language in the context of direct and indirect intercultural communication.

Pupils of Grades 5-6 are fulfilling their cultural competence, in particular, through the following mandatory outcomes: understanding and reproducing the content of what has been heard, reacting tolerantly (particularly using certain etiquette formulas, as well as ethically expressing one's own attitude); appropriate use of certain means of artistic expression in one's own speech and justification of their use, adhering to norms in the selection of verbal means; producing written statements to express one's thoughts, feelings and attitudes, interacting with others in writing, in particular in real-time mode, adhering to the relevant norms of literary language; tolerantly asserting one's own position, focusing, if necessary, on the common and different opinions of other participants in the discussion; observing etiquette norms in online communication; using works of art as a means of communication with others. Enrichment of aesthetic and emotional-sensory experience by a pupil is achieved through the analysis of the emotional state of characters, their actions, for modeling one's own behavior and formation of basic moral and ethical norms, showing tolerance.

The following mandatory learning outcomes outline the aspects of cultural competence in pupils of Grades 79: taking active part in communication, using some methods of communicative interaction in accordance with the communication purpose and situation; appropriate use of quotations, in particular from works of original and translated literature, to support and add expression to one's own views, ideas, beliefs; selection and use of the relevant verbal and nonverbal means for effective communication, adapting them to the communicative situation and intentions, in view of the social and cultural context; appropriate use of various means of artistic expression in one's own speech and justification of their use; making a positive impact on the emotional state of group communication participants, appreciating one's own cultural tradition and showing respect for others; producing written statements concerning one's thoughts, feelings and attitudes, interaction with others in writing, in particular in real time, adhering to the relevant norms of literary language; use of the knowledge of language in verbal creativity; tolerantly asserting one's own position, focusing, if necessary, on the common and different views of other participants in the discussion. As a result, a pupil can compare texts on similar topics, including literary works (original and translated texts) of different styles, literary schools, different cultures, and find common and different aspects in literary works (original and translated texts) of different cultures with reference to the topic, problematics, style, presentation format, structure, time of creation, etc. Enrichment of aesthetic and emotional-sensory experience by the student is achieved through the substantiation of the aesthetic and artistic value of the read texts (original and translated) in the cultural-historical context with regard to the importance of translated literature as a source of enrichment of national culture.

2. Education area "Mathematics" aims at achievement by pupils of mathematical competence in connection with other key competencies necessary for successful educational and professional activity throughout life, which assumes the acquisition of the knowledge system, improving skills and methods of solving purely mathematical and practical problems; developing logical thinking and individual's psychological qualities; understanding the possibilities of applying mathematics in personal and social life. Within this area, cultural competence covers the following skills and attitudes:

Skills:

- to perceive mathematics in works of art;

- to draw figures, graphs, pictures, diagrams, charts, illustrate mathematical models;

- to perform the necessary calculations to establish proportions, reproduce perspectives, create three-dimensional compositions.

Attitudes:

- understanding the relationship between mathematics and culture based on examples from painting, music, architecture, etc.;

- understanding the importance of the contribution of mathematicians to world culture.

3. Education area "Natural Science" aims at forming a personality with a scientific worldview, capable of interacting with nature in a civilized manner. Formation of cultural competence in this area is carried out by way of acquisition of the following skills and attitudes:

Skills:

- to apply the achievements of natural sciences and technologies as well as technical means for the realization of artistic ideas;

- to explain the natural science foundations in different art forms.

Attitudes:

- understanding the role of natural sciences and technologies in the development of culture;

- respect for science as an element of world culture.

4. Education area "Technologies" aims at the realization of pupils' creative potential, formation of critical and technical thinking; willingness to change the environment without harming it, by means of modern technologies and design; capacity for entrepreneurial and innovative activ- 
ity, partnership; ability to use equipment and technologies for self-aid, cultural and national self-expression.

Cultural competence covers the following skills and attitudes:

$$
\text { Skills: }
$$

- to express one's own ideas, experiences, and feelings through self-made articles, including works of decorative and applied arts;

- to promote the decorative and applied arts of one's community, native land, country and the art originating from European cultural heritage;

- to study technologies of producing objects of decorative and applied arts.

\section{Attitudes:}

- respect for the creative expression of ideas, folk customs, traditions;

- preservation and development of traditional technologies of producing objects of decorative and applied arts.

5. Education area "Information Technology" aims at the development of a personality capable of solving problems with the use of digital devices and technologies for development, creative self-expression, attaining personal and social well-being, using critical thinking and skills to act safely and responsibly in the information society. Cultural competence covers the following skills and attitudes within this area:

Skills:

- to express one's opinion in an intelligent and logical manner, to maintain a reasoned dialogue, with due account for the national and cultural specifics of the interlocutors in virtual space;

- to create diverse media products using information technologies;

- to take into account the artistic and aesthetic aspects in the creation of information products (websites, drawings, texts, etc.).

\section{Attitudes:}

- awareness of one's own cultural identity, respect for the diversity of cultural expression of others in the global information society;

- willingness to defend the importance of continuous development of one's own information culture.

6. Education area "Social Science and Health Care" aims at forming the competencies that facilitate social and interpersonal interaction, strengthening and maintaining one's health and safety through self-awareness, ability to learn, entrepreneurship, professional socialization of personal life for achieving personal and social well-being. The following skills and attitudes reflect the aspects of cultural competence:

Skills:

- to develop one's emotional sphere based on the perception of art, to apply creative abilities and life skills in various situations, in particular in the professional environment;

- to regulate one's own psycho-emotional and physical state by means of art;

- to critically assess the impact of culture on the safety, health, and well-being of citizens.
Attitudes:

- recognizing the value of a creative approach to achieving well-being;

- perception of art as a means of self-identification, transferring of spiritual values;

- ethical and responsible attitude to intellectual property.

Pupils' mandatory learning outcomes in this education area assume the acquisition of cultural competence by way of gaining knowledge about responsible consumption, charity, and its nature, manifestations of humanity, sensitivity, helping others, supporting people with special needs, forming ethical attitudes towards gender, race, national, gender, age and physical differences between people, tolerant attitude to the views and beliefs, interests and needs of others. This section also covers the formation in pupils of respect for living beings and fighting animal cruelty.

7. Education area "Civics and History" aims at pupil's personality development by way of understanding the past, present and relationship between the former and the latter, the mutual interference of global and local processes; formation of the identity of a Ukrainian citizen, his/her active civic engagement based on the principles of democracy, respect for human rights and freedoms. The pupil's cultural competence within this area covers the following skills and attitudes:

Skills:

- to describe the main trends in the development of culture historically and in the present day;

- to compare cultures, their values, traditions, ways of living;

- to identify the impact of belonging to different communities and external factors shaping a person's views and beliefs;

- to identify and explain what it means for him/her to belong to a socio-cultural community.

Attitudes:

- appreciation of social and cultural diversity, justification of its benefits and challenges in modern society;

- conscious preservation and development of one's own culture, respect for the cultures of other peoples;

- responsible behavior and caring for cultural heritage sites;

- openness to intercultural dialogue.

8. Education area "Arts" aims at holistic development of successful personality in the course of the acquisition of the artistic heritage of mankind; awareness of one's own national identity within cross-cultural communication; formation of a pupil's key competencies and subject matter artistic competencies necessary for artistic and creative self-expression; fulfillment of one's creative potential, involvement in cultural processes in Ukraine and abroad.

Skills:

- to be well-versed in cultural diversity; identify manifestations of interaction between different cultures and their contribution to sustainable development; to analyze the ways of expressing and communicating ideas in different cultures through art;

- to develop one's own emotional sphere on the ba- 
sis of the perception of art and artistic activity;

- to interpret, make an aesthetic assessment of environmental phenomena/objects (in particular, evaluate media resources from an aesthetic standpoint);

- to create artistic images using different art forms; produce and realize ideas;

- to show respect for intellectual and cultural property;

- to identify different ways of artistic communication between the subjects of artistic dialogue.

Attitudes:

- awareness of universal, aesthetic, and artistic values, transmitted by the art of different regions of the world;

- showing respect for the artistic heritage of the Ukrainian people and taking pride in the latter, showing respect and tolerance in regard to the cultural diversity of different regions of the world;

- awareness of one's own identity in the world cultural heritage;

- the need to promote national culture through one's own artistic activity;

- understanding the need to preserve the artistic heritage of mankind;

- understanding the importance of aesthetic factors in everyday life.

The education area of art covers the necessary theoretical data, as well as a system of concepts through which artistic activity, artistic literacy, and artistic communication are realized in various ways. In the course of the education process, a pupil acquires a scope of new knowledge, in particular about cultural diversity and the impact of art on an individual, as well as about the dialogue in art, which are directly related to cultural competence.

9. Education area "Physical Education" aims at the formation of social and other key competencies, strong motivation in pupils to do physical training and sports to achieve harmonious development of physical fitness, improve vital physical skills, expand one's movement experience.

Skills:

- to determine the needs and problems that need to be solved to achieve a high level of an individual's physical fitness;

- to express one's cultural potential through physical activity;

- to correctly express one's opinion, give reason, and maintain dialogue;

- to consider historical and Ukraine's national traditions in physical education in everyday life;

- to improve one's movement culture;

- to observe moral standards of behavior when interacting with others in the process of physical education;

- to express one's individuality via the methods of physical education.

Attitudes:

- awareness of the importance of an individual's physical education and a sense of cultural identity, respect for the diversity of sports heritage in culture;

- awareness of self-expression and self-realization opportunities offered by physical education and sports.
The Standard of the Basic Education provides for the possibility to implement the above areas in schools in different ways, in particular through school subjects or integrated courses, as well as to flexibly allocate study time for their acquisition. The state standard also specifies the total academic workload in the basic curricula, provides the guidelines for assessing academic achievements and approaches to the final state attestation. It provides 7 variants of the basic curriculum according to the educational needs of schoolchildren and also specifies the recommended, minimum and maximum number of class hours per area and in general.

The Standard will become the basis for the development of a model curriculum for a basic school education that will consist of the variants of model curricula and catalogs of model curricula, as well as of other educational programs consisted with the requirements of the Law of Ukraine "On Full General Secondary Education" subject to expert examination and approval. In parallel, a system for assessing competencies acquired at the level of basic secondary education will be developed.

Starting from September 2021, pilot testing of teaching materials in 5 pilot classes of the New Ukrainian School will begin. Also, the respective advanced training for teachers is planned for 2021-2022.

\section{Discussion}

In the context of reforming the content of education, the National Doctrine of Ukraine defines a competency approach as one of the keys to transformation (Ovcharuk, 2003). A researcher emphasizes the importance of understanding the concept of "key competencies" in the content of education, and knowing "what particular competencies should be taught and what the teaching outcomes should be" (Ovcharuk, 2003: 13). In addition, the National Doctrine of Ukraine analyzes also an issue of implementing a competency approach in terms of improving the quality of educational content from a comparative pedagogical perspective and suggests the appropriate ways of its development, provided in the recommendations, which were laid out in the Law of Ukraine "On Education" (2017). Among the principles of the state policy and of educational activity, the Law of Ukraine "On Education" (2017) can distinguish an inextricable connection between education and the world and national history, culture, national traditions (Article 6 of the Law); achieving the goal of full general secondary education is possible by forming key competencies essential for any modern person to live a successful life (Article 12). Some of the key competencies included in the list are comparatively new to the Ukrainian educational environment, specifically cultural competence which should contribute to the formation of a culture of dialogue and a culture of living (Article 55, paragraph 3) in today's globalized world.

These points underline international researchers, who have generated much knowledge in this area, developing a body of research that identifies attitudinal approaches and skills to help successfully adapt and work in a new cultural environment (e.g. Ang, Van Dyne\& Koh, 2008; Mol, Born, Willemsen, \& Van der Molen, 2005; Sussman, 2000; Thomas \& Fitzsimmons, Liao 2017). They stressed that un- 
derstanding the nature of competence in schools and universities is one of the pedagogy's most important goals. The lack of theoretical clarity and consensus on what constitutes the attributes of competence leads to uneven cultural education. The article of Liu, Gill and Li (2021) summarized that an ecological system is needed to achieve the holistic development of cultural competence. The affective, cognitive, and behavioral domains must be achieved at the individual level.

The concept of "cultural competence" which derives from cultural awareness and cultural perception is widely used by Ukrainian sociologists who introduced it to explain the concept of intercultural communication and involve the public in cultural life. However, this term is new for Ukrainian studies. Having been studying the scientific and theoretical literature and scientific findings of practical research, it appears that the source base on issues of cultural competence in Ukraine is quite limited. The largest study was conducted as a part of a joint US-Ukrainian research project CQS, and the findings are presented in the work titled "Cultural Competence in Ukraine" (Johnson, 2014). The said sociological study was the first one in Ukraine dedicated to this subject where the scale of cultural competence was used.

Today, the world's scholars transform "cultural competence" from the construction to an approach based on cultural intelligence. Cultural intelligence (CQ - cultural quotient or cultural intelligence) offers a particular advantage in a modern world which is critical to overcoming global constraints not only in spatial terms but also in cultural aspects. Intercultural interaction and relevant processes can be analyzed through the prism, terms, and definitions of the notion of "cultural intelligence". At the same time, instead of the term "cultural intelligence", the concept of "cultural competence" is widely used by Ukrainian sociologists (Kostenko, 2010). For example, within the project "Cultural Competency and Cultural Intelligence: Analysis Using Ukraine as an Example", Ukrainian sociologists choose to translate CQS as "cultural competence".

The study of Van Driel and Gabrenya (2013) was developed to elaborate and evaluate quantitative indicators of cultural competence. The researcher distinguishes between conceptualizations of cultural competence based on attributes and performance, arguing that "most definitions and models of cultural competence at the individual level assume a causal relationship between antecedents, such as personality skills, and performance outcomes". In the context of the formation of cultural competence during teaching activities at educational institutions, its interdisciplinary and complex nature is worth mentioning. According to Holovina (2015: 151), cultural competence includes:

\section{References}

1. Derzhavnyi Standart Povnoii Zahalnoii Serednioii Osvity [The State Standard of the Basic Secondary Education] (2020). Retrieved 06.04.2021 from Government Portal: $\quad$ https://www.kmu.gov.ua/npas/pro-deyaki-pitannya-derzhavnih-standartiv-povnoyi-zagalnoyiserednoyi-osviti-i300920-898 [in Ukrainian].

2. Derzhavnyi Standart Pochatkovoii Osvity [The State Standard of Primary Education] (2019). Retrieved
- competency in relation to the institutional norms of social organization;

- competency in relation to conventional norms of social and cultural regulation; everyday erudition in the social and humanitarian spheres;

- competency in relation to short-term, but relevant examples of social prestige;

- level of proficiency in social communication languages: natural spoken language (oral and written), special languages and jargon, languages of etiquette and ceremony, political, religious, social, and ethnographic symbols, the semantics of prestige attributes, social labeling, etc.

\section{Conclusion}

The concept analysis was mainly based on the latest research papers and the Law of Ukraine "On Education" (2017), the National Doctrine for Education Development (2002), as well as the State Standard of Basic Secondary Education (2020), providing the background for continuing the New Ukrainian School reform in Grades 5-9 since 2022 in the course of reforming the Ukrainian educational system. The analysis of the provisions of the State Standard demonstrated the key role of cultural competence which is achieved through the acquisition of relevant knowledge and skills in each education area. The aspects of this competence are particularly prominent in foreign language learning within the Languages and Literatures education area. The basis on which the competence is formed includes personal qualities, abilities, pupils' previous personal, social, cultural, and educational experience; their learning incentives; knowledge, skills, and attitudes that are formed in educational, socio-cultural, and informational environments, as well as in various life situations. The cornerstone of competence is culture, which is not only the result of human activity but also represents historically formed working methods and commonly acceptable behavioral acts, manner of communication, ways, and techniques used to express one's feelings, as well as the level of thinking. It is expected that the acquisition of cultural competence by pupils will allow them to independently understand and freely use at their discretion the entire range of acquired competencies and expertise pertaining to sociocultural and public, institutional and conventional norms and regulators of behavior in the course of responsive social communication, including in different languages. It is obvious that cultural competence will allow individuals to effectively achieve significant results and will become a prerequisite for solving various environmental, political, socio-economic, cultural problems in the development of mankind.

06.04.2021 from Verkhovna Rada of Ukraine: https://zakon.rada.gov.ua/laws/show/688-2019-п\#Text [in Ukrainian].

3. Holovina, N.I. (2015). Problemy formuvannia kulturnoi kompetentnosti osobystosti v konteksti reformuvannia vyshchoi shkoly [Problems of personality cultural competence formation in the context of higher education reform]. Filosofski obrii-Philosophical horizons, 33, 147156 [in Ukrainian]. 
4. Johnson, R.B. (2014). Cultural competence in Ukraine. Journal of European Economy, 13 (3), 236-247. Retrieved 06.04.2021 from Space at West Ukrainian National University: http://dspace.wunu.edu.ua/bitstream/316497/12820/1/Johnson\%20R..pdf [in English].

5. Jia Liu, Elaine Gill and Shuangyu Li (2021). Revisiting cultural competence. The Clinical Teacher, 18, 191-197. https://doi.org/10.1111/tct.13269. Retrieved 27.09.2021 from https://onlinelibrary.wiley.com/doi/full/10.1111/tct.13269 [in English].

6. Kostenko, N.V. (2010). Subkulturna variatyvnist ukrainskoho sotsiumu [Subcultural variability of Ukrainian society]. Kyiv: Instytut sotsiolohii NAN Ukrainy. [in Ukrainian].

7. Mol, S. T., Born, M. P., Willemsen, E., \& Van der Molen, H. T. (2005). Predicting expatriate job performance for selection purposes: A quantitative review. Journal of Cross-Cultural Psychology, 35, 590-620. Retrieved 27.09.2021 from https://www.academia.edu/47000763/Predicting_Expatriate Job_Performance_for_Selection_Purposes_A_Quantitative_Review [in English].

8. Ovcharuk, O.V. (2003). Competencies as a Key to Educational Content Renewal. In Reform Strategy for Education in Ukraine: Educational Policy Recommendations. (pp.13-43). Kyiv: KIS. Retrieved 06.04.2021 from CORE: https://core.ac.uk/download/pdf/11871107.pdf\#page=13 [in English].

9. Pro Natsionalnu Doktryny rozvytku osvity v Ukraini [On National Doctrine for Education Development in Ukraine] (2002). Retrieved 06.04.2021 from Verkhovna Rada of Ukraine: http://zakon3.rada.gov.ua/laws/show/347/2002 [in Ukrainian].

10. Sussman, N. M. (2000). The dynamic nature of cultural identity throughout cultural transitions: Why home is not so sweet. Personality and Social Psychology Review, 4, 355-373. Retrieved 27.09.2021 from https://www.semanticscholar.org/paper/The-Dynamic-Nature-of-Cultural-Identity-Throughout-Suss-

$\underline{\text { man/b436603d06b6ef298a28ba2a00b9b6c93697691c }}$ [in English].

11. The Law of Ukraine on Education (2017). Retrieved 06.04.2021 from Verkhovna Rada of Ukraine: https://mon.gov.ua/ua/npa/law-education [in English].

12. Thomas, D. C., Fitzsimmons, S. R., Liao Yuan (2017). From crossing cultures to straddling them: An empirical examination of outcomes for multicultural employees. Journal of International Business Studies, 48(1), 6389. DOI:10.1057/s41267-016-0053-9. Retrieved 27.09.2021 from https://www.researchgate.net/publication/312276132_From crossing cultures to straddling them_An_empirical_examination_of_outcomes_for_multicultural_employees [in English].

13. Van Dyne, L., Ang, S., \& Koh, C. (2008). Development and validation of the CQS: The Cultural Intelligence Scale. In S. Ang \& L. van Dyne (Eds.), Handbook of cultural intelligence: Theory, measurement and applications. Armonk, NY: M.E. Sharpe, pp. 159-173. Retrieved
27.09.2021 from http://soonang.com/wp-content/uploads/2011/10/Chapter-29-Cultural-Intelligence-Ang-

Van-Dyne-Tan.pdf [in English].

14. Van Driel, M., Gabrenya W. K. (2013). Organizational Cross-Cultural Competence: Approaches to Measurement. Journal of Cross-Cultural Psychology, -44(6), 874-899.DOI: 10.1177/0022022112466944. Retrieved 27.09.2021 from https://www.researchgate.net/publication/258144423 [in English].

15. Zakon Ukrainy pro Osvitu [The Law of Ukraine on Education] (1991). Retrieved 06.04.2021 from Verkhovna Rada of Ukraine: https://zakon.rada.gov.ua/laws/show/1060-12 [in Ukrainian].

\section{Література}

1. Головіна, Н. І. Проблеми формування культурної компетентності особистості в контексті реформування вищої школи. Філософські обрії. 2015. № 33. С. $147-156$.

2. Державний стандарт базової середньої освіти: Постанова Кабінету Міністрів України від 30 вересня 2020 №898. URL: https://www.kmu.gov.ua/npas/pro-deyaki-pitannyaderzhavnih-standartiv-povnoyi-zagalnoyi-serednoyiosviti-i300920-898 (Дата звернення: 27.09.2021).

3. Державний стандарт початкової освіти: Постанова Кабінету Міністрів України від 24 липня 2019 №688. URL: https://zakon.rada.gov.ua/laws/show/6882019-п\#Техt (Дата звернення: 27.09.2021).

4. Про освіту: Закон України від 23.05.1991 № 1060-XII. Закон втратив чинність на підставі Закону № 2145-VIII від 05.09.2017. URL: https://zakon.rada.gov.ua/laws/show/1060-12 (Дата звернення: 27.09.2021).

5. Про освіту: Закон України від 05.09.2017 № 2145-VIII. URL: https://mon.gov.ua/ua/npa/law-education (Дата звернення: 27.09.2021).

6. Костенко Н. В. Субкультурна варіативність українського соціуму. Київ: Інститут соціології НАН України, 2010. 287 с. URL: https://i-soc.com.ua/assets/files/book/petrushina/svus.pdf

7. Національна доктрина розвитку освіти: Указ президента від 17 квітня 2002 року N 347/2002. URL: http://zakon3.rada.gov.ua/laws/show/347/2002 (Дата звернення: 27.09.2021).

8. Johnson R. B. (2014). Cultural competence in Ukraine. Journal of European Economy, 13 (3), 236-247. URL: http://dspace.wunu.edu.ua/bitstream/316497/12820/1/Johnson\%20R.pdf

9. Jia Liu, Elaine Gill and Shuangyu Li (2021). Revisiting cultural competence. The Clinical Teacher, 18, 191-197. DOI: https://doi.org/10.1111/tct.13269.

10. Mol S. T., Born M. P., Willemsen E., \& Van der Molen H. T. (2005). Predicting expatriate job performance for selection purposes: A quantitative review. Journal of Cross-Cultural Psychology, 35, 590-620. URL: https://www.academia.edu/47000763/Predicting Expatriate Job_Performance for_Selection_Purposes_A Quantitative_Review. 
11. Ovcharuk O. V. (2003). Competencies as a Key to Educational Content Renewal. In Reform Strategy for Education in Ukraine: Educational Policy Recommendations. (pp.13-43). Kyiv: KIS. URL: https://core.ac.uk/download/pdf/11871107.pdf\#page=13.

12. Sussman N. M. (2000). The dynamic nature of cultural identity throughout cultural transitions: Why home is not so sweet. Personality and Social Psychology Review, 4, 355-373. URL: https://www.semanticscholar.org/paper/The-Dynamic-Nature-of-Cultural-Identity-Throughout-Sussman/b436603d06b6ef298a28ba2a00b9b6c93697691c.

13. Thomas D. C., Fitzsimmons S. R., Liao Yuan (2017). From crossing cultures to straddling them: An em- pirical examination of outcomes for multicultural employees. Journal of International Business Studies, 48(1), 6389. DOI: $10.1057 / \mathrm{s} 41267-016-0053-9$.

14. Van Dyne L., Ang S., \& Koh C. (2008). Development and validation of the CQS: The Cultural Intelligence Scale. In S. Ang \& L. van Dyne (Eds.), Handbook of cultural intelligence: Theory, measurement and applications. Armonk, NY: M. E. Sharpe, pp. 159-173. URL: http://soonang.com/wp-content/uploads/2011/10/Chapter29-Cultural-Intelligence-Ang-Van-Dyne-Tan.pdf.

15. Van Driel M., Gabrenya W. K. (2013). Organizational Cross-Cultural Competence: Approaches to Measurement. Journal of Cross-Cultural Psychology, 44(6), 874-899. DOI: 10.1177/0022022112466944.

\section{КУЛЬТУРНА КОМПЕТЕНТНІСТЬ ЯК ОДНА 3 КЛЮЧОВИХ КОМПЕТЕНТНОСТЕЙ} У РЕФОРМІ СИСТЕМИ ОСВІТИ УКРАЇНИ

Метою статті є конкретизація змісту формування культурної компетентності, визначеної у стандарті базової середньої освіти, та очікуваних результатів ї̈ сформованості у контексті освіти продовж життя. Культурна компетентність як освітній термін вперше була визначена в Законі України «Про освіту» Україні (2017) та у Державному стандарті базової середньої освіти (2020) для 5 - 12 класів. У статті проаналізовано прочес формування культурної компетентності та очікувані результати навчання. Результати дослідження сформульовані на підставі логіко-семантичного аналізу та структурно-функціонального уточнення сутності культурної компетентності, виокремлення ї̈ структурних компонентів на підставі аналізу положень прийнятих регулятивних документів, стандартів та рекомендацій щзодо освітньої політики, а також рефлексивний аналіз концепиії культурної компетентності у прачях національних та міжнародних дослідників. Культурна компетентність особистості постає у формі ключової компетентності, яка дозволяє їй самостійно зрозуміти й вільно використовувати на свій розсуд увесь обсяг здобутих компетентностей та компетенцій щзодо соціально-культурних та суспільних, інституцііональних та конвенціональних норм і регуляторів поведінки у процесі мобільної соціальної комунікації, у тому числі різними мовами. Наукове обговорення концепції компетентності є актуальним питанням, зумовленим реформуванням української системи освіти відповідно до світової моделі.

Ключові слова: культурна компетентність, ключова компетентність, розвиток культурної компетентності, базова середня освіта, українська освітня система, Закон України «Про освіту», Державний стандарт базової середньої освіти України. 